\title{
Soğuk Dövme Yöntemi ile Örnek Bir Ürün Tasarımı, Üretimi ve Tasarımda Ergonominin Rolü
}

\author{
Alper Baygut ${ }^{1 *}$ \\ 1* BOLT Bağlantı Elemanları San. Tic. A.Ş., BOLT Ar-Ge Merkezi, Bursa, Türkiye, (ORCID: 0000-0003-4775-1066), alper.baygut@bolt.com.tr \\ (International Conference on Design, Research and Development (RDCONF) 2021 - 15-18 December 2021)
}

(DOI: $10.31590 /$ josat.1039297)

ATIF/REFERENCE: Baygut, A. (2021). Soğuk Dövme Yöntemi ile Örnek Bir Ürün Tasarımı, Üretimi ve Tasarımda Ergonominin Önemi. Avrupa Bilim ve Teknoloji Dergisi, (32), 76-85.

$\ddot{O} \mathbf{z}$

Bu çalışmada, talaşlı imalat yöntemi kullanılarak imal edilen bağlantı elemanının üretimi, proses verimliliği ve kalite artışı kriterlerine dayalı tasarım çalışmaları yapılmıştır. Tasarım kriterlerinde yapılacak revizyonlarla soğuk dövme ile şekillendirme yöntemi esas alınarak yeni bir tasarım geliştirilmiştir. Bu kapsamda, tasarım metodolojisi ve ergonomi konuları incelenmiştir. Tasarım kavramını oluşturan işlev-malzeme-şekil ve işlem metodu bileşenleri, tasarım kriterleri açısından değerlendirilmiştir. Ayrıca, tasarımda ergonominin ana kriterleri ile üretim yöntemi irdelenmiştir. Geliştirilen proses soğuk dövme ile üretilen örnek bir ürün üzerinde uygulanmış ve sonuçlar detaylı olarak verilmiştir.

Anahtar Kelimeler: Tasarım, Ergonomi, Soğuk Şekillendirme, Dövme.

\section{A Sample Product Design, Production with Cold Forming and The Role Of The Ergonomics in Design}

\begin{abstract}
In this study, design studies were carried out based on the production, process efficiency and quality increase criteria of the fastener manufactured using the machining method. With the revisions to be made in the design criteria, a new design has been developed based on the cold forming method. In this context, design methodology and ergonomics issues were examined. Function-materialshape and process method components that make up the design concept are evaluated in terms of design criteria. In addition, the main criteria of ergonomics in design and production method are examined. The developed process was applied on a sample product produced by cold forming and the results are given in detail.
\end{abstract}

Keywords: Design, Ergonomics, Cold Forming, Forming.

\footnotetext{
*Sorumlu Yazar: alper.baygut@bolt.com.tr
} 


\section{Giriş}

Tasarım, imal edilebilecek bir üründen, yeni bir fikre veya piyasanın ihtiyaç duyduğu detaylı bilgiye dönüştürme işlemidir. Her bir basamak, malzemelerle ilgili ürünün elde edilmesinde kullanılacak yöntemin belirlenmesi kararını gerektirmektedir. Genellikle, malzeme tercihi tasarımcı tarafindan belirlenmektedir. Bazen diğer bir yol olarak; yeni bir ürün, var olan bir gelişim, yeni malzeme tarafindan elde edilmektedir veya önerilmektedir. Mühendisler için kullanışlı malzeme sayısı 40.000 ila 80.000 arasındadır. Her ne kadar standartlaştırma çalışmalarıyla bu sayı azaltılmaya çalışılsa da her geçen gün kullanılabilir, yeni nesil malzemelerin geliştirilmesi daha fazla tercih hakkı sunmaktadır (Çiltepe, 2010).

Tasarımın hedefi, üretilmesi amaçlanan makine ekipmanı için, müşteri sınır şartları kapsamında optimum seviyede çalışacak ucuz hammaddeyi seçmektir. Seçim kriterleri değerlendirildiğinde; kullanım yeri ile birlikte çalışma koşullarına bağlı olarak öncelikle sınır şartları net olarak bilinmeli ve müşteri istekleri incelenerek prosese en uygun nitelikleri sağlayacak en verimli malzemeyi belirlemek gerekmektedir (Pala, 2015; Çetin vd., 2020).

Ürünün kendisi; düzenekler, alt düzenekler ve parçalardan oluşan teknik bir sistem olarak değerlendirilmektedir. Ashby’e (1999) göre gerekli görev çalışmaları bir yöntemde toplanmaktadır. Konuyla ilgili "kedi tanımı"nda olduğu gibi, sistem (kedi) düzeneklerden (kafa, gövde, kuyruk, dört bacak vb.) oluşmaktadır. Bu arayış var olan tasarımı analiz etmek için yararlı bir yol olup, yeni tasarımların birleştirilmesinde ve tasarım süreçlerinin çoğunda yardımcı olamayabilmektedir.

Malzeme seçimindeki temel amaç, tasarımı yapılan ürünün istenilen işlevi yerine getirebilmesi için, belirlenen çalışma şartları altında işleyebilen, maliyeti düşük ve en uzun ömürlü malzemenin belirlenmesidir. Bu amaca ulaşabilmek için tasarım prosesi aşamalarını iyi anlamak önem arz etmektedir. Tasarım prosesi aşamaları ise ihtiyacın belirlenmesi, ihtiyacın net tanımı, ihtiyaç hakkında bilgi toplama, çözüm önerisi belirleme, tasarımın gerçekleşmesine yönelik araştırma, sistemin tasarlanması, kalite kontrol ve ürünün imalatıdır. Bu süreçte aktif olarak rol alan tasarımcının, ihtiyacı, üründen beklenen özellikleri, çalışma ve üretim şartlarını göz önünde bulundurarak en uygun malzemeyi seçmesi gerekmektedir (Ashby, 1999).

İsteklerin çok yönlülüğü ve karmaşıklığı göz önünde bulundurularak tasarımda sistematiği ortaya koyma konusunda, malzeme, tasarım ve imalat teknikleri ile ilgili faktörlere ve bunların birbiriyle karşılıklı etkileşimde olmalarına mutlaka dikkat edilmelidir. Bunun için tüm malzemelerin kullanım ve imalat karakteristikleri listeler halinde düzenlenmelidir. $\mathrm{Bu}$ çalışma ne kadar temele iner ve kapsamlı olursa, yanılma oranı ve sonrasında düzeltme gereği o ölçüde azalır (Topbaş, 1993).

\section{1. İşlev, Malzeme, Şekil Ve İşlem Metodunun Tasarım Kriterleri Açısından Değerlendirilmesi}

Bir malzeme ve işlemin seçimi şekil tercihinden ayrı tutulamaz. Şekil kelimesi diş şekli ve gerektiğinde, peteğimsi veya hücreli yapılarda olduğu gibi, iç şekli ifade etmesi için kullanılmaktadır. Şekil kazandırma ilk olarak işlem yapılandırmayı, malzeme, taşıma, bitirme ve birleştirme işlemlerini içermektedir. $\mathrm{Bu}$ işlemlere malzeme dahil edilmektedir. İşlev, malzeme, şekil ve işlem birbirini etkilemektedir (Topbaş, 1993).

\subsection{Tasarımda Ergonomi}

Yunanca ergon (iş anlamında) ve nomos (yasa anlamında) kelimelerinden oluşan ergonomi sözcüğ̈̈; insan mühendisliği, insan faktörü mühendisliği ve iş bilimi olarak nitelendirilmektedir. Aynı zamanda ergonomi insan, makine ve işin birbiriyle uyumunu inceleyen bir bilim dalıdır. Ergonominin bugüne kadar yapılmış birçok tanımı bulunmakla birlikte insanın sağlığını koruyarak güvenliğini sağlamak ve iş verimliliğini üst seviyeye çıkaracak uygulamalar bütünü olması tüm tanımların ortak noktasıdır (Uzun vd., 2011; Çalışkan vd., 2012).

Ergonomi bilimi; esas olarak işçinin sağlık açısından korunmasını sağlayarak, olabilecek en az emek ve zorlayıcı fiziksel faaliyet ile en yüksek iş verimliliğini hedeflemektedir. İmalat sanayisinde bulunan bazı hatlardaki (montaj vb.) ergonomi çalışmalarının ön sırada gelen temel amacı, çalışanların iş yapış sırasında maruz kalacakları gerilmelere neden olacak duruş pozisyonlarını ortadan kaldıracak düzenlemeleri yapmaktır (Güner vd., 2011; Sağıroğlu vd., 2015).

İş yerlerinde, çalışan insanlardan gerçekleştirilmesi istenilen işlerle, insanın temel birtakım özellikleri arasında uyum olması gerekmektedir. Ergonomi, insanların fiziksel, psikolojik özelliklerini ve kapasitelerini göz önüne alarak, organizasyondaki verimliliği artırmaya ve insan-makine-çevre uyumunun temel prensiplerini ortaya koymaya çalışan ve insanın güvenli, sağlıklı, konforlu koşullar içinde olması için çözüm üretilmesine katkıda bulunan bir disiplindir. Ergonomi alanında en çok çalışılan konular; metot ve teknikler, insan karakteristikleri, iş tasarımı ve organizasyon, sağlık ve güvenlik, işyeri ve ekipman tasarımıdır.

OSHA' ya göre (İş Güvenliği ve Sağlığı İdaresi) ergonomiyi basit bir iş çalışması olarak tanımlayabiliriz. Daha açık bir ifadeyle, ergonominin, işin çalışana uyması için fiziksel olarak zorlamak yerine, işi çalışana uyacak şekilde tasarlama bilimi olduğu belirtilmiştir. Görevlerin, çalışma alanlarının, araçların ve ekipmanların çalışanlara uyarlanması, bir çalışanın vücudundaki fiziksel stresi azaltmaya yardımcı olabilir ve kas-iskelet sistemi bozukluklarını ortadan kaldırabilir. Ergonomi; psikoloji, biyomekanik, fizyoloji, kinesiyoloji, endüstriyel hijyen ve antropometri gibi pek çok bilimsel disiplinden yararlanmaktadır.

\section{Materyal ve Metot}

Tasarımı yapılacak ürün değerlendirildiğinde, birtakım fırsatlar karşımıza çıkmaktadır. Otomotiv sektöründe koltuk parçası olarak kullanılan ürün, talaşlı imalat yöntemi ile üretilmekte olup, firma tarafından sinırlı adetlerde tedarik edilmektedir. Talaşlı imalat ile proses hızı arttırılamamakta ve ürünün sabit sayıda üretimi gerçekleşmektedir. Prosesteki herhangi bir aksaklıktan kaynaklı üretim durması ile parça tedarik edilememesi, kullanıcıyı zor durumda bırakmaktadır. Talaşlı imalat prosesi; yüksek maliyetli, üretim hızı yavaş ve ürün üzerinde istenmeyen yapıların oluşması gibi sebepler bakımından dezavantajlı bir yöntemdir. Ayrıca üretimde kalite sürekliliği de sağlanamamaktadır. $\mathrm{Bu}$ olumsuzlukların giderilmesinde kullanılabilecek fırsatlar değerlendirildiğinde; soğuk dövme destekli ürün tasarımı, fayda-maliyet açısından müşteriyi kuvvetlendirecek en önemli girdi olacaktır. Soğuk dövme ile, tamamı talaşlı imalatla üretilen parçanın daha verimli 
ve uygun maliyetlerle üretilebilme firsatı yakalanmıştır. Üretim hızı, ürün yüzey özellikleri ve düşük maliyet çalışmanın gerçekleştirilmesinde itici güç unsurları olmuştur.

\section{1. Şekil Verme Yöntemleri}

Tasarım kriterleri değerlendirildiğinde, çalışma kapsamındaki ürünün simülasyon destekli olarak; talaşlı imalat, soğuk dövme, 1lık dövme, sıcak dövme olmak üzere dört farklı üretim yöntemi ile üretilebilmesi mümkündür.

Talaşlı İmalat (talaşlı üretim); malzemeyi özel takımlar kullanarak yüzeyinden talaş kaldırılmasının sağlanması ile son şekline getirilmesine verilen prosesin adıdır. Bu proses ile yüzey özellikleri, parça kademeleri, kademe kesitleri ve ölçülerinin tezgah gücü ile kesici takım kullanılarak talaş kaldırma suretiyle şekil verebilme işlemidir (Çelik, 20019).

Dövmede, ilk olarak basit bir parça (örneğin kütük), istenilen son şekli elde etmek için iki takım (veya iki kalıp) arasında plastik olarak deformasyona uğratılır. Böylece, bir parçanın basit geometrisi, istenilen şekle sahip olan takımlar vasıtasıyla karmaşı geometriye dönüştürülür ve takım/malzeme arayüzüyle deforme olan malzemeye basınç uygulanır. Dövme işleminde, bir metalin dövülerek kırılmadan veya çatlamadan şekil değiştirebilme kabiliyeti dövülebilirlik olarak ifade edilmektedir. Düşük kuvvetlerle çatlamadan dövülerek şekillendirilebilen malzemeler için "dövülebilirliği iyi”" kavramı kullanılır. Dövülebilirliğin ölçülmesi amacıyla çekme, basma, burulma gibi testlerden yararlanılmaktadır. Dövme işlemi, temelde bir plastik şekil verme işlemi olduğu için, metal akış yönü, deformasyonun büyüklüğü, sürtünme ve sicaklık iş parçaların özelliklerini büyük ölçüde etkilemektedir (Altan vd., 2005; Çapan, 2003; Başdemir vd.; 2018).

Malzeme kaybının minimize edilerek hammadde tasarrufunun sağlanması, proses süresinin kısa olması, yüzey kalitesinin yüksek olması ve dar tolerans aralıklarıyla üretimin sağlanabilmesi soğuk dövme yönteminin en önemli avantajları arasında sayılmaktadır (Misırlı, 2006). Örneğin, $1 \mathrm{~kg}$ hammaddeden talaşlı imalat yöntemi kullanılarak elde edilen bir iş parças1, sıcak dövme yöntemi kullanılarak 800-900 gr hammaddeden imal edilirken bu değer soğuk dövme yöntemi kullanıldığında 350-400 gr'a kadar düşebilmektedir. Bahsedilen bu oranlarlar parçanın ölçülerine bağlı olarak değişkenlik gösterebilmektedir. Diğer bir yandan, soğuk dövme yöntemiyle imal edilen bir parça, talaşlı imalat yöntemiyle kıyaslandığında, işlem süresi bakımından $\% 70-80$ oranlarında avantaj sağlamaktadır. Sağladığı bu avantajlar göz önüne alındığında soğuk dövme yöntemi birçok uygulama alanı için tercih sebebi olmaktadır (Altan vd.,2005; Çapan, 2003; Başdemir vd.,2018; Misirl1, 2006; Dieter, 1961).

\subsection{Tasarımda Kullanılan Bilgi Teknolojileri ve Soğuk Dövmede Simülasyon Uygulamaları}

Günümüzde, geniş bir kullanım alanına sahip olan ve sürekli olarak gelişim gösteren sonlu elemanlar analizi araçları, seçilmiş bir prosesin gerçek makinede deneme yanılma yöntemi ile yapılması yerine bilgisayar ortamında gerçeğe yakın oranda gerçekleştirilmesine olanak vermektedir. Sonlu elemanlar analizi kullanılarak yapılan çalışmalar sayesinde endüstriyel uygulamalarda maliyet kazancı ve kalite artışı sağlanmaktadır. Simülasyonlar sayesinde üretim ve öncesi gerçekleştirilen tüm ara prosesler için performans, şekil alabilirlik ve ön değerlendirme için birçok bilgi elde edilmektedir. Bugün, endüstriyel çalışmalarda yoğun olarak kullanılan simulasyon uygulamaları akademik bilgi üretmede de yaygın ve etkin şekilde kullanılmaktadır.

\subsection{Hammadde Seçimi}

Hammaddeler dövme prosesine uygun olarak, tasarım kriterleri kapsamında seçilmelidir. Tasarım alternatifi malzemeler Tablo 1'de görüldüğü şekilde seçilmelidir.

Tablo 1. Dövme Işleminde Malzeme Seçme Kriterleri (Sheljaskov, 1994)

\begin{tabular}{|c|c|c|c|}
\hline & Sicak & Ilık & Soğuk \\
\hline $\begin{array}{c}\text { İş Parçasının } \\
\text { Ağırlığı }\end{array}$ & $<60 \mathrm{~kg}$ & $<10 \mathrm{~kg}$ & $<2 \mathrm{~kg}$ \\
\hline Çelik Sınıfı & Herhangi & $\begin{array}{c}\mathrm{C} \text { (Karbon) } \\
\text { istenir. Diğer } \\
\text { alaşım } \\
\text { elementleri } \\
<\% 10\end{array}$ & $\begin{array}{c}\text { Düşük } \\
\text { alaşımlı } \\
\text { çelikler }\end{array}$ \\
\hline Şekil & Herhangi kesit & \multicolumn{2}{|c|}{ Dönel - simetrik kesit } \\
\hline Yüzey Kalitesi & Düşük & Orta & Yüksek \\
\hline Ara İşlemler & Gerekli değil & Gerekli değil & $\begin{array}{l}\text { Tavlama } \\
\text { ve fosfat } \\
\text { kaplama }\end{array}$ \\
\hline $\begin{array}{c}\text { Deformasyon } \\
\text { Basıncı }\end{array}$ & Düşük & Orta & Yüksek \\
\hline $\begin{array}{c}\text { Enerji } \\
\text { Maliyeti }\end{array}$ & Yüksek & Orta & Düşük \\
\hline Toleranslar & Bol & Yakın & En yakın \\
\hline $\begin{array}{l}\text { Takım } \\
\text { Maliyeti }\end{array}$ & En Düşük & Yüksek & Yüksek \\
\hline
\end{tabular}

\section{4. Ürün Geliştirme}

Mevcut ürün farklı üretim yöntemleri ile üretilebilmektedir. İmalatta üretim platformu geliştirme prosesi kapsamında Şekil 1' de görülen yöntemler kullanılabilir.

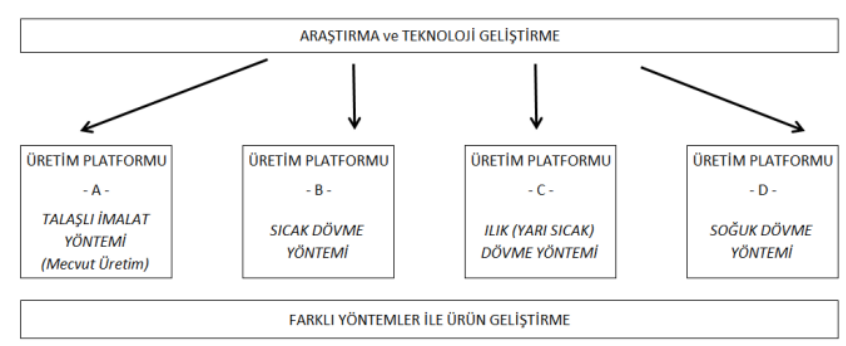

Şekil 1. Üretim Yöntemleri 


\subsection{1. Üretici - Müşteri Görüsşmeleri}

Tasarım değerlendirildiğinde, ürün üzerinde bazı değişiklikler yapılması gerektiği sonucuna varılmıştır. İlgili değişiklikler Tablo 2' de açıklanmıştır. Müşteri kuruluşun satın alma, kalite, üretim politikalarına göre değerlendirmeler yapılmış, üründen beklenen gereklilikler belirlenmiş ve iş-zaman planları ortaya konulmuştur.

Rekabet stratejisine göre, müşteri odaklı yaklaşım ve maliyet liderliği ön plandadır. Bu çalışmada da müşteri için özel bir ürün tasarlanmıştır. $\mathrm{Bu}$ ürünün aynı zamanda fiyat bakımından ilgili pazarda rekabetçi niteliğinin olması göz önünde bulundurulmuştur.
Müşteri ile ürün özelinde karşıllklı görüşmeler sağlanarak ürün gereklilikleri ile müşteri ihtiyaçları belirlenmiştir. $\mathrm{Bu}$ gereklilik ve ihtiyaçların başında ürüne ait mekanik, metalurjik özellikler ve birtakım bölgelerdeki kritik ölçümler gelmektedir. Metalurjik ve mekanik özelliklere yönelik yapılan literatür araştırmaları ile kullanım yerine uygun mukavemet değeri sağlayacak malzeme seçimi yapılmıştır.

Dengeleme metoduna göre çalışma, ürün hattında değişiklik içermezken, üretim sürecinde simülasyon destekli üretim ile süreç değişikliğine sahiptir (Wheelwrighy vd. 1992).

Tablo 2. Müssteri Görüşmesi (Gereklilikler - İhtiyaçlar)

\begin{tabular}{|c|c|c|}
\hline Sorular & Müşteri Gereklilikleri - İhtiyaçları & Yorumlanmış İhtiyaçlar \\
\hline Hammadde & 11SMnPb36 olmalıdır. & $\begin{array}{l}\text { İstenen hammadde talaşlı imalat } \\
\text { proesine uygundur. Soğuk dövme } \\
\text { prosesi için 20MnB4 hammadde } \\
\text { kullanılması uygun olacaktır. }\end{array}$ \\
\hline Mukavemet & $\begin{array}{l}\text { Kopma Mukavemeti en az } \\
350 \mathrm{~N} / \mathrm{mm}^{2} \text { olmalıdır. }\end{array}$ & $\begin{array}{l}\text { 20MnB4 hammadde kullanıldığında } \\
\text { Kopma mukavemeti en az } 580 \\
\text { N/mm² olacaktır. }\end{array}$ \\
\hline Kafa Formu & Dairesel Olmalıdır. & \multirow{2}{*}{$\begin{array}{l}\text { Kafa kısmı soğuk dövme ile } \\
\text { oluşturulmak istenmektedir. İki } \\
\text { tırnaklı dairesel yapı oluşturulabilir. }\end{array}$} \\
\hline $\begin{array}{l}\text { Kafa Kanal - Tirnak } \\
\text { Formu }\end{array}$ & $\begin{array}{c}\text { Parçanın takıldığı yerde hareket } \\
\text { etmemesi için Kafa bölgesinde kanal } \\
\text { olmalıdır. }\end{array}$ & \\
\hline Kafa Çapı & $\varnothing 30+-0,2 \mathrm{~mm}$ olmalıdır. & \multirow{2}{*}{$\begin{array}{l}\text { Soğuk dövme ile istenilen çapta } \\
\text { üretilebilir. }\end{array}$} \\
\hline Dış Çap & $\varnothing 19-0,1 \mathrm{~mm}$ olmalıdır. & \\
\hline İç Diş Formu & 7/16 - 20 UNF Formunda olmalıdır. & $\begin{array}{l}\text { İç delik delme ve iç diş oluşturma } \\
\text { işlemi talaşlı imalat desteği ile } \\
\text { yapılacağından, istenilen özelliklerde } \\
\text { oluşturulabilir. }\end{array}$ \\
\hline
\end{tabular}

Ergonomik Durum

Montaj Kolaylığ 1
İki tırnaklı dairesel yapı sayesinde montaj kolaylığı sağlanacaktır.

\begin{tabular}{lcl}
\hline Yıllık İhtiyaç & 500.000 adet/yıl ihtiyaç vardır. & $\begin{array}{l}\text { Talaşlı imalat destekli soğuk dövme } \\
\text { prosesi ile } \\
500.000 \text { adet/yıl üretim sağlanabilir. }\end{array}$ \\
\hline Proje genel ihtiyacı & $\begin{array}{c}\text { Ürün bir yıldan sonra yıllık 1.000.000 } \\
\text { adet olarak 5 yıl boyunca tedarik } \\
\text { edilecektir. }\end{array}$ & $\begin{array}{l}1.000 .000 \text { adet/yıl üretim talaşlı } \\
\text { imalat destekli karşılanabilir. }\end{array}$ \\
\hline Birim Fiyat & Hedef fiyat 6,5 TL dir. & $\begin{array}{l}\text { Yığın üretimde hedef fiyatın altında } \\
\text { fiyat verilebilir. }\end{array}$ \\
\hline Kalite Belgesi & $\begin{array}{c}\text { Tedarikçinin IATF 16949 kalite } \\
\text { belgesine sahip olması gereklidir. }\end{array}$ & IATF 16949 kalite belgesi mevcuttur. \\
\hline
\end{tabular}

Yapılan görüşmeler neticesinde müşteri gerekliliklerinin soğuk dövme ve talaşlı imalat desteği ile elde edilebileceği görülmektedir. 


\section{Avrupa Bilim ve Teknoloji Dergisi}

\subsubsection{Müşteri Şikayetleri}

Firsatlar değerlendirildiğinde hem firma hem de müşteri için bazı firsatların olduğu görülmüştür. Kazan - kazan çerçevesinde iki tarafında kazanımının olması öngörülmüştür. Müşteri görüşmesi sırasında müşteri şikayetleri de değerlendirilmiş ve bu Tablo 3' de verilen değerlendirme neticesinde tasarım faaliyetleri planlanmıştır.

Tablo 3. Müşteri Şikayetleri Tablosu

\begin{tabular}{|c|c|}
\hline Mevcut Üründeki Müşteri Şikayetleri & Yeni Tasarım ile Geliştirilecek Özellikler \\
\hline $\begin{array}{l}\text { Kullanım yerinde istenen kuvvetten daha düşük } \\
\text { kuvvette kopma olması }\end{array}$ & $\begin{array}{l}\text { Dövme hammaddesi ile mukavemet artı̧ı } \\
\text { sağlanacak. }\end{array}$ \\
\hline Kullanım yerinden, yuvasından çıkması & Kafa bölgesinde özel tırnak tasarlanacak \\
\hline $\begin{array}{l}\text { İç diş kısmının } 7 / 16-20 \mathrm{UNF} \text { diş olması. İçe } \\
\text { girecek civatanın tedariğinin zor olması }\end{array}$ & $\begin{array}{l}\text { Uygun görülürse iç diş Metrik standardında } \\
\text { üretilecek. Metrik standardında cıvata tedariği daha } \\
\text { kolay olacaktır. }\end{array}$ \\
\hline Yüzeyde talaşlı imalat izlerinin olması & $\begin{array}{l}\text { Soğuk dövme ile yüzey kalitesi iyileşecektir. } \\
\text { Yüzeyde işleme izi olmayacaktır. }\end{array}$ \\
\hline $\begin{array}{l}\text { İstenilen miktarda üretim yapılamaması, üretim } \\
\text { hızının düşük olması }\end{array}$ & $\begin{array}{l}\text { Soğuk dövme ile birim zamanda üretim adedi çok } \\
\text { daha yüksektir. }\end{array}$ \\
\hline Ürün fiyatının hedef fiyat üzerinde olması & $\begin{array}{l}\text { Soğuk dövme ile yığın üretim olacağı için hedef } \\
\text { fiyat yakalanacaktır. }\end{array}$ \\
\hline Kafa girintisinde ölçü tutmaması & $\begin{array}{l}\text { Soğuk dövme prosesinde ölçü tolerans1 diğer } \\
\text { proseslere göre Kafa bölgesinde tırnak } \\
\text { oluşturularak hassas ölçü elde edilecektir. }\end{array}$ \\
\hline $\begin{array}{l}\text { Montaj hattına gelen parçalardan bir kısmının iç diş } \\
\text { özelliklerinin (diş formu uygunsuzluğu, diş } \\
\text { kırıkları, dişte çapak vb. hatalar) uygun olmaması }\end{array}$ & $\begin{array}{l}\text { İç diş oluşturulduktan sonra mastar kontrolü } \\
\text { yapılacaktır. }\end{array}$ \\
\hline Mevcut tedarikçinin \%100 seçme yapamaması & $\begin{array}{l}\% 100 \text { seçme makinası ile tüm ölçüsel kontroller } \\
\text { yapılacaktır. }\end{array}$ \\
\hline
\end{tabular}

\subsubsection{Görev Tanımları Çalışması}

Mevcut tasarıma göre görev tanımları çizelgesi hazırlanmış ve Tablo 4 'de gösterilmiştir. Tablo incelendiğinde; kilit iş hedefleri, birincil pazar, ikincil pazar, varsayımlar ve paydaşlar açıklanarak öngörüler listelenmiştir.

Tablo 4. Tasarım ve Görev Tanımları

Görev Tanımı : Tamamı Talaşı İmalat Yöntemiyle Üretilen Bağlantı Elemanının Soğuk Dövme Prosesi İle Üretilebilmesi İçin Simulasyon Destekli Ürün Tasarımı

Proje ile birlikte talaşı imalat yöntemi kullanılarak üretilen emniyet kemeri bağlantı burçlarına ait üretim sürecinin, üretim verimliliği ve kalite artışına dayalı soğuk şekillendirme esaslı olarak yeniden tasarlanması hedeflenmektedir. Kalıp tasarımı ve proses simülasyonu ile gerçek üretime geçmeden önce tasarım

Ürün Açıklaması doğrulama veya dizayn iyileştirme esaslı Tasarım faaliyetleri sonucunda yeni bir üretim süreci elde edilmiş olacaktır. Tasarım projesinde, soğuk dövme prosesi ile üretimi gerçekleştirilecek prototip emniyet kemeri bağlantı parçalarını; soğuk şekillendirme yöntemi ve simülasyon uygulamalarını birleştirerek; proses tasarım, ürün tasarımı ve geliştirmesi, üretim yöntemi revizyonu - maliyet düşürme 


\begin{tabular}{|c|c|}
\hline & $\begin{array}{lcccccccc}\text { aşamalarını içine } & \text { alan } & \text { bir } & \text { proje } & \text { çevrimi } & \text { ile } & \text { Tasarım çalışmaları } \\
\text { gerçekleştirilecektir. }\end{array}$ \\
\hline Kilit İş Hedefleri & $\begin{array}{l}\text { **Tasarım öncesi yapılan mühendislik hesaplarında ve iş etütlerinde benzer } \\
\text { ürünler için talaşlı imalat yerine soğuk dövme ile üretime başlandığında; } \\
\text { hammadde kullanımında \%50 avantaj ve üretim hızında ise } \% 75 \text { oranında artı̧̧ } \\
\text { olacağı ön görülmüştür. } \\
\text { **Diğer taraftan ürün özellikleri açısından da soğuk dövme ile şekillendirme } \\
\text { sırasında cold work veya work hardening sırasında mikroyapısal değişimler } \\
\text { (deformasyon yönündeki malzeme akışı) sayesinde talaşlı imalata göre daha } \\
\text { mukavemetli ürün elde edilmesi hedeflenmektedir. } \\
\text { **Soğuk Dövme yöntemi ile şu anda ve gelecek dönemde müşteri ihtiyaçlarının } \\
\text { adet olarak karşılanabilmesi. } \\
\text { **Kafa formunun özel tasarım yapılması ile ürünün kullanıldığı yerden } \\
\text { çıkmamasını sağlaması } \\
\text { **Soğuk dövme yöntemi ile yığın üretim gerçekleşeceği için hedef fiyatın } \\
\text { tutturulması. }\end{array}$ \\
\hline Birincil Pazar & Otomotiv Ana Yan Sanayi Koltuk Firmaları (Yurtiçi ve Yurtdışı) \\
\hline İkincil Pazar & $\begin{array}{l}\text { Koltuk Üreten Diğer Yurtiçi ve Yurtdışı Firmalar } \\
\text { (Otobüs, Kamyon, Tır, Minibüs, Forklift, Golf Aracı, Motorsiklet, İş Makinaları, } \\
\text { Traktör vb) }\end{array}$ \\
\hline Varsayımlar & $\begin{array}{l}\text { **Üretim yöntemi geliştirilmesi } \\
\text { **Yüksek Mukavemet } \\
\text { **Üretim hızındaki artış } \\
\text { **Maliyet İyileştirme } \\
\text { **Kolay Montaj } \\
\text { **Iş planı kolaylığı } \\
\text { **Kanban Sistemini uygulama kolaylığı } \\
\text { **Yalın üretim yapılabilirliği } \\
\text { **Ergonomi uygulamaları }\end{array}$ \\
\hline Paydaşlar & $\begin{array}{l}* * \text { Koltuk üreten firmalar } \\
* * \text { Son kullanıcılar } \\
* * \text { Otomotiv ana sanayi }\end{array}$ \\
\hline
\end{tabular}

\subsection{4.İhtiyaç Ölçüt Analizi ve Çalışması}

Tasarıma özel ihtiyaç - ölçüt analizi yapıldığında, tasarım aşamasında ürün üzerinde dikkat edilmesi gereken bölgeler Tablo 5 'de gösterildiği gibi tespit edilmiş ve değerlendirilmiştir.
İhtiyaçlara ait ölçümlerin değerlendirilmeleri yapılmış, tasarım, üretim ve ergonomiye ait kriterler belirlenmiştir.

Tablo 5.İhtiyaç Ölçüt Analizi

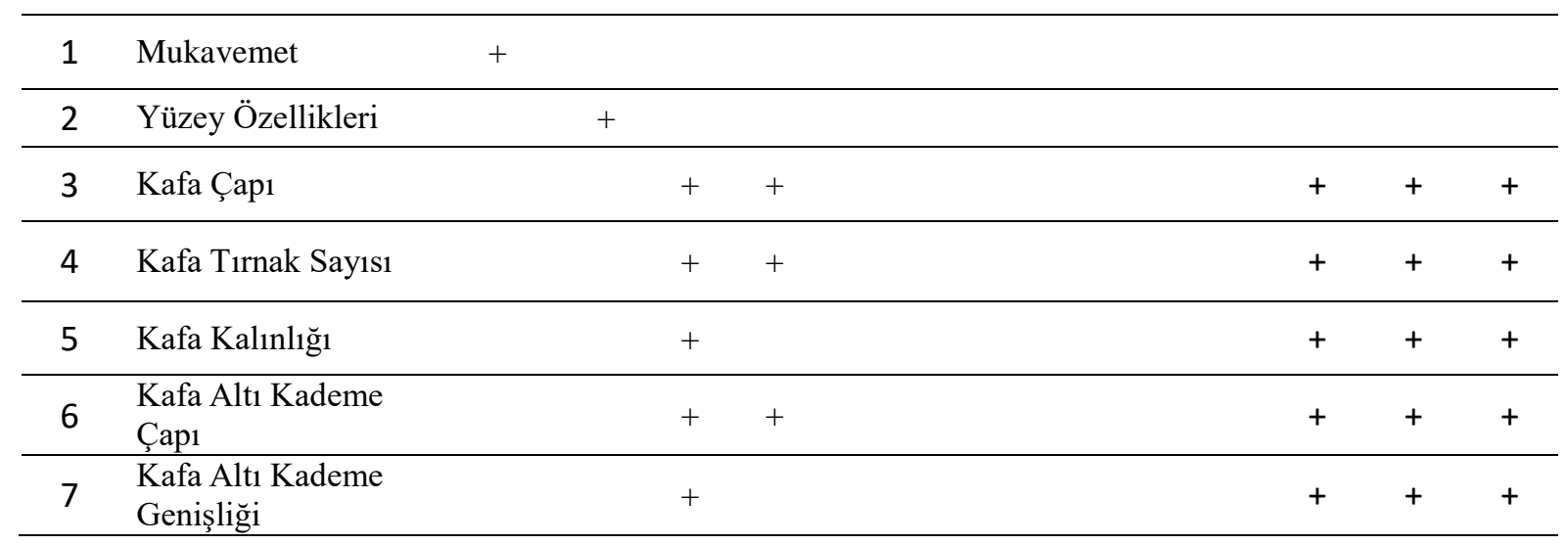




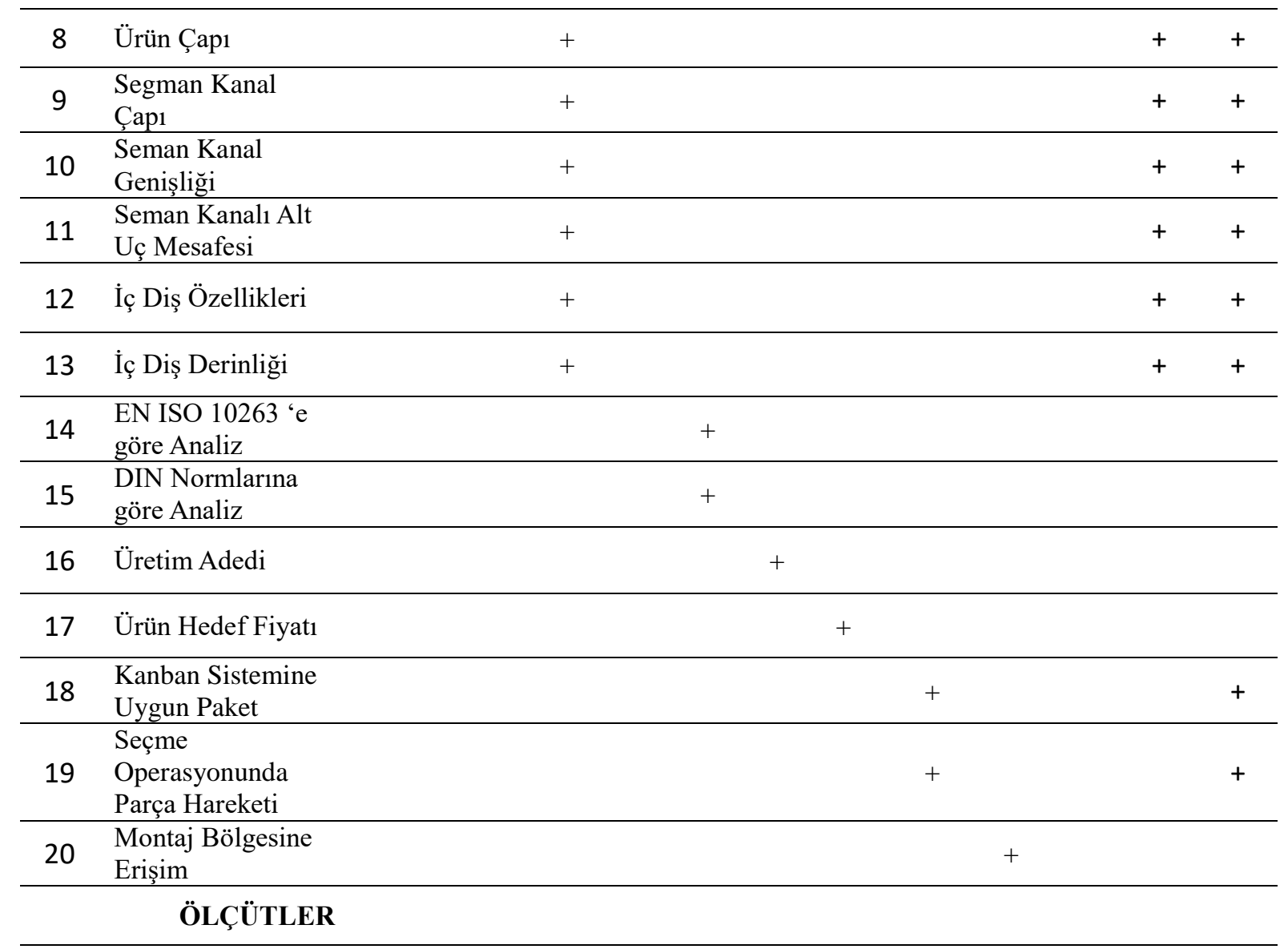

\begin{tabular}{|c|c|c|c|c|c|c|c|c|c|c|c|c|}
\hline 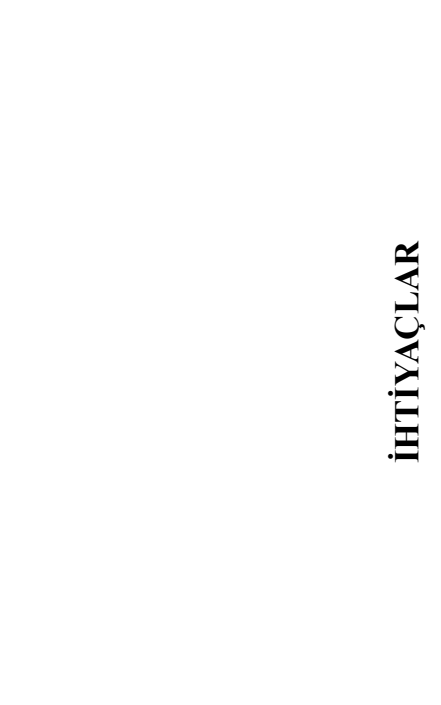 & 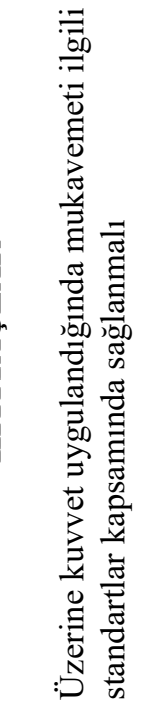 & 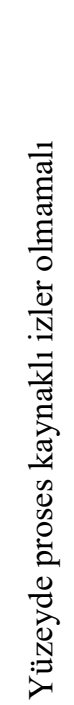 & 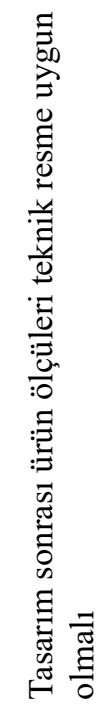 & 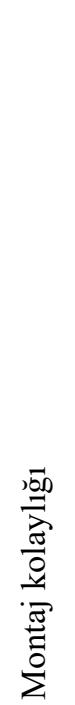 & 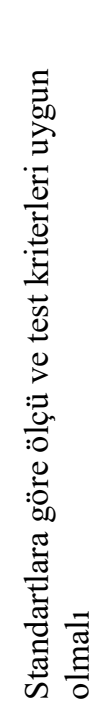 & 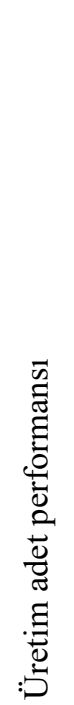 & 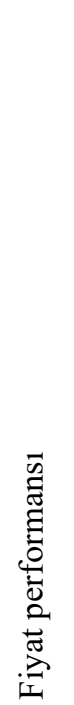 & 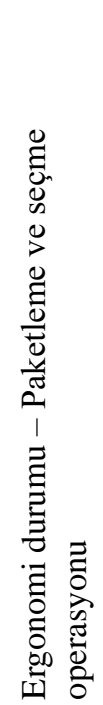 & 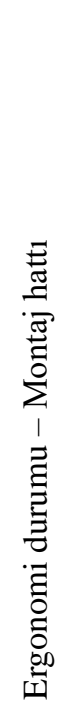 & 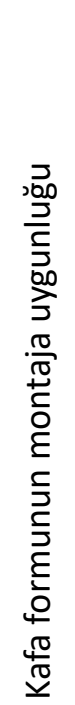 & 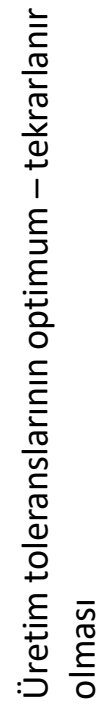 & 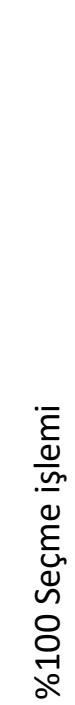 \\
\hline & 1 & 2 & 3 & 4 & 5 & 6 & 7 & 8 & 9 & 10 & 11 & 12 \\
\hline
\end{tabular}

\subsection{5. Ürün Maliyet ve Verimlilik Çalışması}

Kullanılan ürün özellikleri ve yeni tasarım özellikleri fayda - maliyet değerlendirilmesi Tablo 6'da yapılmıştır.

Tablo 6.Maliyet Verimlilik Analizi

\begin{tabular}{cccc}
\hline Açıklama & $\begin{array}{c}\text { Mevcut Durum } \\
\text { (Talaşlı İmalat) }\end{array}$ & $\begin{array}{c}\text { Öngörülen Durum } \\
\text { (Soğuk Dövme) }\end{array}$ & $\begin{array}{c}\text { Öngörülen Soğuk } \\
\text { Dövme Avantajı }\end{array}$ \\
\hline Ağırlık & Brüt $-330 \mathrm{gr}$ & Brüt $-150 \mathrm{gr}$ & Yaklaşı \% 55 \\
\hline
\end{tabular}




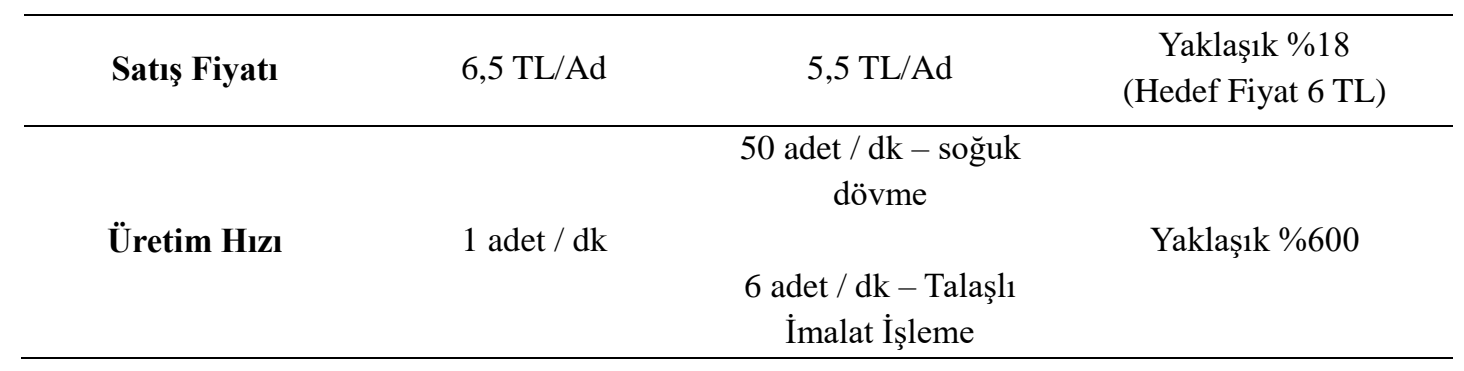

\section{Araştırma Sonuçları ve Tartışma}

\subsection{Alternatif Üretim Yöntemlerinin Değerlendirilmesi}

Metal malzeme şekillendirme yöntemleri incelendiğinde; talaşlı imalat, sıcak dövme ve soğuk dövme yöntemlerinin olduğu görülmüştür.

Çalışmadaki parça yapısı incelendiğinde; iç delik delme, iç diş çekme ve segman kanalı işlemleri hangi yöntem ile üretim olursa olsun talaşlı imalat ile işlenmelidir. Çalışma kapsamında talaşlı imalat destekli en verimli prosesin seçimi yapılmıştır.

Alternatif üretim yöntemlerinden biri de soğuk dövme yöntemidir. Soğuk dövme yöntemi; alternatif üretim proseslerine göre mekanik ve yüzey performanslarının gelişmiş olması, birim zamanda elde edilen parça sayısının yüksek olması, prosesin oda sıcaklığında uygulanabilmesi, proseste malzeme yüzeyinde tufal gibi istenmeyen yapıların meydana gelmemesi, nihai ürün üzerindeki ölçü toleranslarının istenen toleranslar kapsamında düşük değerlerde olması gibi avantajlarından dolayı karmaşı 1 k şekilli parçalarının üretilebilmesi için kullanılan bir yöntemdir. Ayrıca, bu yöntem ile malzeme tasarrufunun sağlanması ve işlem süresinin kısalması da, ilgili yöntemin tercih edilmesinde rol oynamaktadır.

Talaşlı imalat yönteminde ise tamamen dolu çelik malzemeden hacim azaltma yöntemi ile üretimde; hammadde ve takım ucu sarfiyatındaki artış ve birim zamandaki imalat sayısındaki düşüşün üretim maliyetlerine olan olumsuz etkisi ile malzemenin mukavemetinde yaratacağ $\breve{g}_{1}$ muhtemel zayıflık, teknik özellikleri - performans kriterlerine de olumsuz etkileri bulunmaktadır.

Soğuk deformasyondaki malzeme akış çizgilerinin yarattığı mukavemet ve süreklilik, talaşlı imalatta gerçekleşmemektedir. Daha az hammadde kullanılarak net-şekilli üretim gerçekleştirilebilen soğuk deformasyonla şekillendirmenin yarattı̆̆ ürünün hem maliyetine hem de performansına etki eden faktörler ile yeniden tasarlanması bu çalışma kapsamında değerlendirilmiş̧tir.

Parça geometrisi, üretim adedi, hammaddenin bulunabilirliği gibi özellikler değerlendirildiğinde iş parçasının üretilebilir olup olmadığı kararına varılmaktadır.

Çalışma kapsamında değerlendirilecek olan özel bağlantı elemanı üretimi soğuk dövme ile gerçekleştirildiğinde, karşımıza tasarım aşamasında değerlendirilmesi gereken birtakım unsurlar çıkmaktadır. Sonuç olarak alternatifler arasında değerlendirme yapıldığında Tablo 7 'de görüldüğü gibi "Konsept Türler Çizelgesi" oluşturulmuştur.
Tablo 7.Konsept Türler Çizelgesi

\section{TASARIM - KONSEPT TÜRLERİ}

\begin{tabular}{|c|c|c|c|c|}
\hline Seçme Kriterleri & $\begin{array}{l}\text { Talaşlı } \\
\text { İmalat }\end{array}$ & $\begin{array}{l}\text { Sicak } \\
\text { Dövme }\end{array}$ & $\begin{array}{c}\text { Ilık } \\
\text { (Yarı } \\
\text { Sicak) } \\
\text { Dövme }\end{array}$ & $\begin{array}{l}\text { Soğuk } \\
\text { Dövme }\end{array}$ \\
\hline $\begin{array}{l}\text { Hammadde } \\
\text { Bulunabilirlik }\end{array}$ & + & + & + & + \\
\hline $\begin{array}{l}\text { Hammadde Şekil } \\
\text { Verme Kolaylığı }\end{array}$ & 0 & + & + & + \\
\hline $\begin{array}{l}\text { İşlem Sonrasında } \\
\text { Yüzey Kalitesi }\end{array}$ & 0 & - & 0 & + \\
\hline $\begin{array}{l}\text { İşlem Hızı (Dakikada } \\
\text { üretilen parça sayısı) }\end{array}$ & - & 0 & 0 & + \\
\hline İşlem Maliyeti & - & - & - & + \\
\hline $\begin{array}{l}\text { Birim Zamanda } \\
\text { Üretilen Ürün Sayısı }\end{array}$ & - & 0 & 0 & + \\
\hline $\begin{array}{l}\text { Üretimde Oluşan } \\
\text { Çapak Miktarı }\end{array}$ & - & 0 & 0 & + \\
\hline Üretim Toleransları & 0 & - & - & + \\
\hline Kalitesel Süreklilik & 0 & - & - & + \\
\hline Parça Birim Fiyatı & - & 0 & 0 & + \\
\hline İlk Yatırım Maliyeti & 0 & - & - & 0 \\
\hline Tedarikçi Yönetimi & - & - & - & + \\
\hline ARTILARI & 1 & 2 & 2 & 11 \\
\hline EŞİTLİKLERİ & 5 & 4 & 5 & 1 \\
\hline EKSİLERİ & 6 & 6 & 5 & 0 \\
\hline $\begin{array}{r}\text { NET } \\
\text { DEĞERLENDİRME }\end{array}$ & -5 & -4 & -3 & 11 \\
\hline
\end{tabular}

Tablo 7 değerlendirildiğinde tasarımı yapılan ürünü en uygun üretim yönteminin soğuk dövme olduğu görülmektedir. $\mathrm{Bu}$ sayede hammadde tasarrufunun sağlanabileceği, üretim kaynaklı sorunların minimize edilebileceği, yatırım maliyetleri 
düşük yeni bir prosesin oluşturulabileceği, birim zamanda üretilen ürün adedinin arttırılabileceği öngörülmüştür.

\subsection{Tasarım Çalışmaları}

Bağlantı elemanlarının soğuk dövme ile üretiminde kullanılan kalıpların ömrünün tahmin edilmesi üretim maliyetlerinin gerçekçi bir şekilde belirlenmesinde önemli bir etkendir. Özellikle daha önce soğuk dövme ile üretilmemiş veya üretimi tecrübe edilmemiş parçaların kalıp ömürlerinin tecrübeye dayalı tahmin yöntemiyle belirlenmesi oldukça zordur.

Metal şekillendirme özellikle soğuk dövme prosesinde en yüksek girdi maliyetlerinin başında kalıp maliyetleri gelmektedir. Simülasyon uygulamaları gerçek üretime geçilmeden önce; kalıp ömürleri tahmini, kalıp ömürlerinin arttırılması ve buna göre kalıpların gerçekçi maliyetlendirme çalışmalarında ipucu verecek öngörüsel ve çözüm odaklı bir araç olarak kullanılmaktadır.

Ayrıca tasarım aşamasında kullanılan simülasyon uygulamaları; kalıplara gelen yük miktarı, yük bölgesi, kalitesel süreklilik gibi maliyete etki eden diğer faktörlerinde analiz edilmesine imkan vermektedir.

Yapılan ön çalışmalar, araştırmalar, toplantılar neticesinde ürün ve proses tasarımı Şekil 2' deki gibi tamamlanmış; prototip ürün üretimi Şekil 3 'deki gibi gerçekleştirilmiştir.
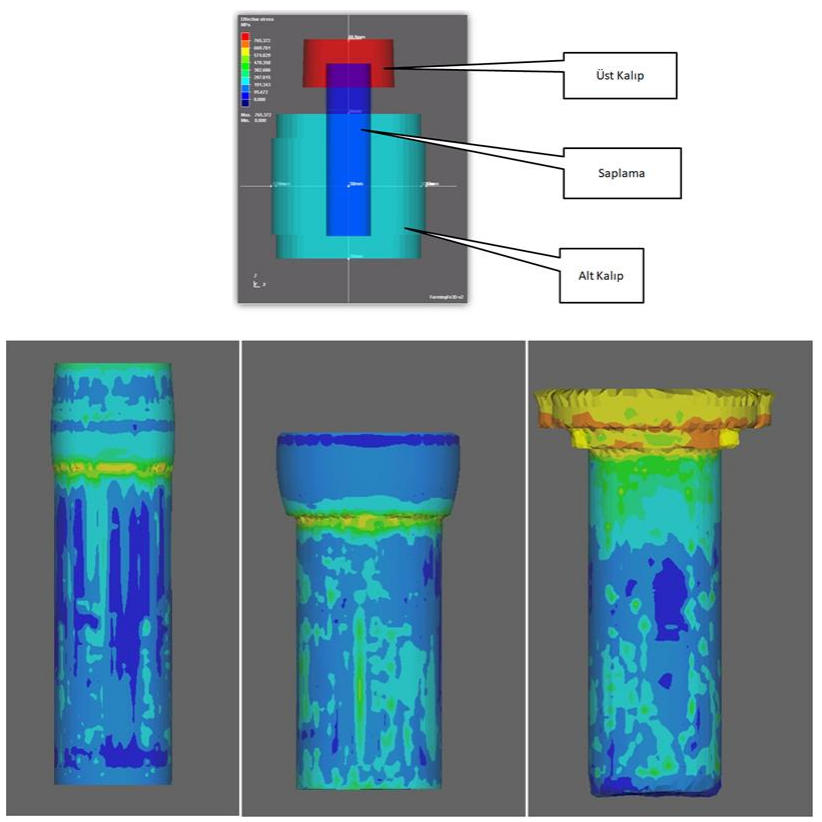

Şekil 2. Simulasyon Destekli Tasarım Çalı̧̧maları
(Simufact.Forming)

Sayısal simülasyon programlarından faydalanılarak, sanal simüle ortamda gerçekleştirilen ön simülasyon çalışmalarının ardından çalışma konusu olan ürünün soğuk dövme yöntemiyle üretilebilirliği doğrulanmıştır. Sanal-simüle ortamda gerçekleştirilen bu deneme işlemleri sayesinde ilgili parçanın herhangi bir üretim kaynaklı problem (çatlama, kırılma, yırtılma) meydana gelmeden soğuk dövme yöntemiyle imal edilebileceği tespit edilmiştir.

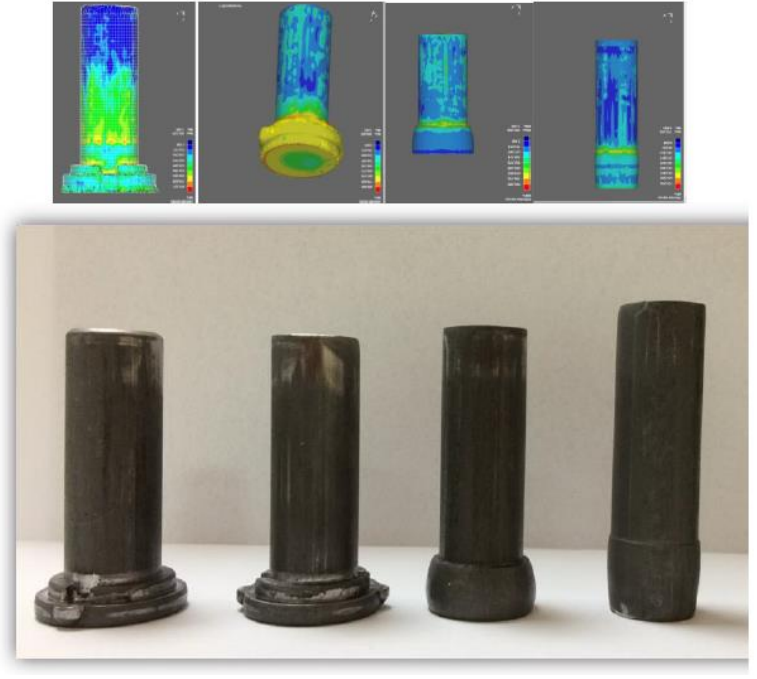

Şekil 3.Prototip Ürün

\subsection{Ergonomi Çalışmaları}

$\mathrm{Bu}$ kapsamda tasarlanmış ürüne ait üretim sonrası proseslerden \%100 seçme ve paketleme operasyonları için ergonomi çalışmaları yapılmıştır.

Parçalar kontrol sırasında uygun (OK) ve uygun olmayan (NOK) şeklinde iki gruba ayrılmaktadır. Şekil 4'te görüldüğü gibi kontrol sonrası parçalar operatörün çalışma şeklini (vücut ergonomisini) bozmayacak şekildedir.
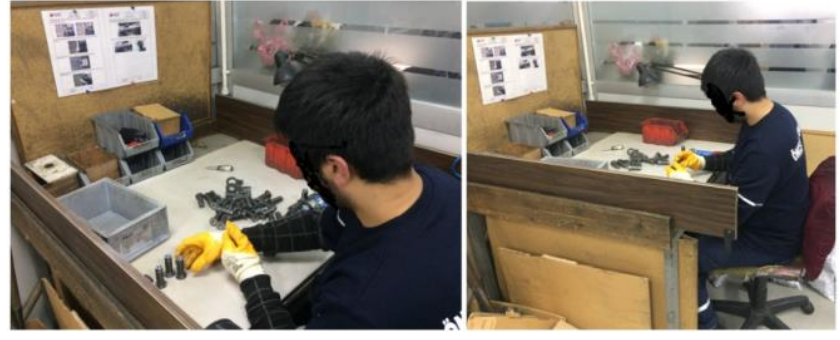

Şekil 4.Seçme Operasyonu

Çalışmanın gerçekleştirilmesi sırasında ergonomik koşulların göz önüne alındığ 1 bir sistematik belirlenmiştir. Bu kapsamda, proses tasarlanırken, parça seçme talimatının göz hizasında, kontrol ekipmanlarının el hizasında ve uygun - uygun olmayan parça kutusunun fiziksel ergonomi kapsamında olmasına dikkat edilmiştir.

Aynı zamanda fiziksel ve örgütsel ergonomi kriterleri de gözden geçirilerek uygun çalışma ortamı tasarlanmıştır. Çalışma ortamı ergonomi kriterleri kapsamında; 1şıklandırılmış, oturma (sandalye) sistemi iyileştirilmiş, uygun-red parça kasaları taşınabilir şekilde ufaltılmış, dinlenme saatleri planlanmıştır.

Taşıma (sevkiyat) kolaylığı bakımdan parçalar Şekil 5 'de gösterildiği gibi ufak kasalara konularak kullanıcıdaki montaj sırasında fiziksel ergonomi gereklilikleri (istasyonlar arasi taşıma operasyonu, parçanın - kasanın kaldırılma operasyonu, kasadan parça alma operasyonu, parçanın ana iskelete montajlanma operasyonu vb.) sağlanmıştır. 

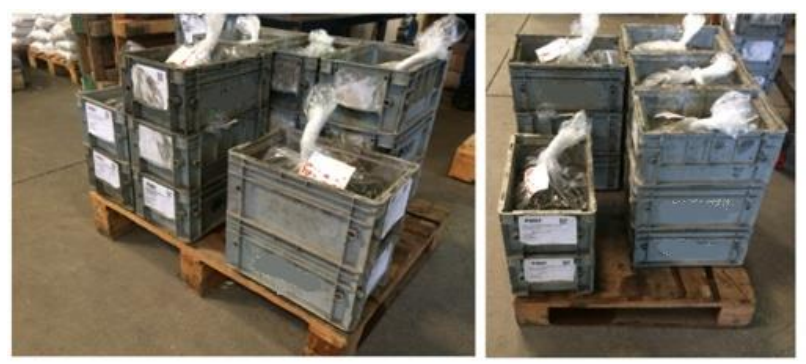

Şekil 5.Taşıma Operasyonu

\section{Sonuç}

Yapılan ergonomi çalışması neticesinde aşağıdaki sonuçlar elde edilmiştir. Buna göre,

a)Talaşlı imalata alternatif olacak şekilde yeni bir proses tasarımı gerçekleştirilmiştir. $\mathrm{Bu}$ yöntem çelik malzemenin plastik şekil alabilirlik özelliğinden faydalanan soğuk dövme prosesidir.

b)Soğuk Dövme tekniğinin avantajı, Metalin plastik şekil alabilirlik özelliği kullanıldığı için, proseslerde talaş oluşmaz bu sayede hammadde girdisi azalmış olur. Talaşlı imalat ile üretilen mamul için kullanılan hammadde ortalama 330 gr iken soğuk dövme tasarımında kullanılması hedeflenen hammadde ortalama 150 g'dır. Soğuk dövme ile kullanılan hammadde de yaklaşık $\% 55$ tasarruf anlamına gelmektedir.

c)Tamamı Talaşı İmalat ile üretilen ürünün üretim hızı 1 adet/dk iken soğuk dövme prosesi + talaşlı imalat ile ortalama 6 adet/dk olması öngörülmüştür. $\mathrm{Bu}$ yöntem ile $\% 600$ oranında üretim artışı ön görülmüştür.

d)Üretim maliyetleri, üretim artışı ve işlem süresinin kısalması ile düşmesi ve bu oranın en az \%15 olması ön görülmüştür.

e)Y1llı 500.000 adet/y1l (sonraki 5 y1l için 1.000.000 adet/yıl) parça ihtiyacı düşünüldüğünde soğuk dövme prosesi ile ilk yıl 90 ton/yıl sonraki beş yıl 180 ton/yıl hammadde tasarrufu sağlanacaktır.

f)Soğuk dövmeye uygun olarak tasarlanmış tırnak formu sayesinde montaj kolaylığı sağlanmış, müşterideki montaj sırasında oluşan kayıp zamanların önüne geçilerek montaj süresi kısaltılması hedeflenmiştir.

g)En önemli maliyet giderlerinin başında gelen kalıp maliyeti (bu parça için yaklaşık 20.000 \$), tasarım aşamasında simülasyon uygulaması kullanılması ile gider olarak karşımıza çıkmamıştır. Simülasyon destekli tasarım ile ayrıca; kalıp yapılmadan, gerçek üretim için makine, işçilik, elektrik, yağ vb. genel giderler olmadan ürün tasarımına ait ürün kriterleri analiz edilmiştir. Tasarım hatalarının önüne geçilmiş, hatalardan kaynaklı öngörülemeyen kalıp kırılmaları en aza indirilmesi hedeflenmiştir.

h)Ergonomi kapsamında yapılan iyileştirmeler neticesinde fiziksel ve örgütsel ergonomi şartları geliştirilerek birim zamanda seçme işlemi yapılan parça sayısı artmıştır. Ayrıca paketleme, taşıma, montaj operasyonları değerlendirildiğinde operatörlerin çalışma şartlarının iyileştiği görülmüştür. $\mathrm{Bu}$ sayede ara operasyonlarda verimlilik artışı elde edilmiştir.

\section{Teşekkür}

Yayının hazırlanmasında emeği geçen Araş. Gör. Tuğçe YAĞCI ve Bolt Bağlantı Elemanları San. Tic. A.Ş Fabrika Müdürü Vedat BAŞDEMİR 'e teşekkür ederim.

\section{Kaynakça}

Altan, T., Ngaile, G., Shen, G. (2005). Cold And Hot Forging: Fundamentals and Applications, Chapter 2. ASM International.

Ashby. M. F. (1999). Materials Selection In Mechanical Design, Oxford UK, Butterworth Heinemann, 225-240.

Başdemir, V., Baygut, A., Çulha, O. (2018). Soğuk Dövme Tekniği İle Bağlantı Elemanı Üretiminde Kullanılan Plastik Şekil Verme Teknolojileri, İleri Teknoloji Bilimleri Dergisi, 7 (3), 18-28.

Çalışkan, M., Findık, F. (2012). Malzeme, Ergonomi Ve Biyomekanik İlişkisi, Sakarya Üni. Fen Bilimleri Enstitüsü Dergisi, 16 (3), 273-282.

Çapan, L. (2003). Metallere Plastik Şekil Verme, Çağlayan Kitabevi, 144.

Çelik, A. (2009). Makine ve Teçhizat, Erzurum Atatürk Üniversitesi, Ders Notları, Ünite 5.

Çetin, M.H., Alvalı, G.T. (2020). Yük Vagonu Bojisi Tasarımında Çok Kriterli Karar Verme Teknikleri İle Malzeme Seçimi, Müh. Bilimleri ve Tasarım Dergisi, 2020, 8 (1), $91-104$.

Çiltepe, E. (2010). Talaşlı İmalatta Malzeme ve Proses Seçim Stratejileri, Yüksek Lisans Tezi, Gazi Üniv. Fen Bilimleri Enstitüsü, Makine Eğitimi.

Dieter, G.E. (1961). Mechanical Metallurgy, McGraw-Hill, 630

Güner, B., Hasgül, S. (2011). Montaj işçilerinde görülen fiziksel rahatsızlıklar ve risk etmenleri üzerine bir çalışma, 11. Ulusal Ergonomi Kongresi.

Mısırlı, C. (2006). Yanal Ekstrüzyon ile Dişli Benzeri Parçaların İmalatı: Analiz ve Deneyler, Doktora Tezi, Trakya Üniv., Fen Bilimleri Enstitüsü.

Pala, İ. (2015). Tekstil Lifleri ile Takviyelendirilmiş Kompozit Malzemelerin Ürün Tasarımında Kullanılması, Yüksek Lisans Tezi, İstanbul Teknik Üni. Fen Bilimleri Enstitüsü.

Sağıroğlu, H., Coşkun, M.B., Erginel, N. (2015). Reba İle Bir Üretim Hattındaki İş İstasyonlarının Ergonomik Risk Analizi, Süleyman Demirel Üniv. Müh. Bilimleri ve Tasarım Dergisi, 3(3), 339-345.

Sheljaskov S. (1994). Current Level of Development of Warm Forging Technology, Journal of Materials Processing Technology, 46, 3-18.

Topbaş, M.A. (1993). Endüstri Malzemeleri Cilt I, Prestij Yayınevi, İstanbul, 80-95.

Uzun, M., Müngen, U. (2011). Çalışma Ortamında Ergonomik Koşulların İşçi Sağlığı ve İş Kazaları Açısından Önemi, İşçi Sağlığı ve İş Güvenliği Sempozyumu.

Wheelwright, S. C., Clark, K. B. (1992). Revolutionizing Product Development: Quantum Leaps in Speed, Efficiency and Quality. New York: Free Press. 